\title{
Petrology and diagenesis of Palaeogene clays from Ølst and Ålbækhoved, Denmark
}

\author{
JENNIFER HUGGETT
}

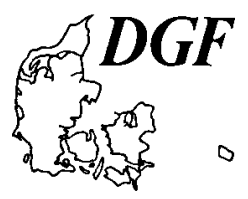
Huggett, J. Petrology and diagenesis of Palaeogene clays from Ølst and Albækhoved,
Denmark. Bulletin of the Geological Society of Denmark, vol. 40 pp. 256-271.
Copenhagen, 1993-12-30. https://doi.org/10.37570/bgsd-1993-40-11

\begin{abstract}
The petrology and diagenesis of Paleocene and Eocene clays from Ølst and Ålbækhoved in northern Jutland, Denmark has been investigated using backscattered electron microscopy and XRD techniques. The Holmehus, Ølst, Røsnæs and Lillebælt Formations were sampled at both localities, whilst at $\emptyset \mathrm{lst}$, the Søvind Marl was also sampled. These sediments are extremely fine grained, smectite-rich, vari-coloured claystones with ash horizons in several formations. Smectite and carbonate minerals are the principal authigenic phases. Smectite is inferred to have formed as a result of alteration of volcanic glass, though it is unclear how much of the smectite is detrital. Three manganese bearing carbonate cements have been identified in all Formations sampled at both localities except the Holmehus Formation. These cements are manganoan calcite, calcian rhodochrosite and manganoan siderite. All occur as equant to subequant rhombs, up to $15 \mu \mathrm{m}$ across, but typically $2-5 \mu \mathrm{m}$. Calcian rhodochrosite is present as overgrowths on rounded clay-size particles of high $\mathrm{Mg}(20 \%)$ calcite, which are either detrital grains or corroded authigenic cement. It also occurs as overgrowths on equant rhombs of earlier formed manganoan calcite. The manganoan siderite occurs as relatively large crystals $(20 \mu \mathrm{m})$ scattered through the clay matrix and as concretions. Calcite cement is present in the Lillebælt and Ølst Formations. Quantitatively it is not as important as the more unusual Mn-bearing calcium carbonates.
\end{abstract}

Jennifer Huggett. Dept. of Geology, Imperial College, Prince Consort Road, London, SW7 2BP. 19 September 1992.

\section{Introduction}

The Upper Paleocene and Eocene marine sediments from Denmark are mainly composed of smectite and other clays. These sediments include approximately 200 volcanic ash layers in various stages of alteration, most of which are associated with the Ølst Formation (Nielsen \& Heilmann-Clausen, 1988). The depositional environment was marine to possibly brackish and well below wave base (Heilmann-Clausen, Nielsen \& Gersner, 1984). Five major depositional phases are recognised: stratigraphically these are identified with the Søvind Marl, Lillebælt, Røsnæs, Ølst and Holmehus Formations. The Eocene-Paleocene lithostratigraphy at Ølst and Ålbækhoved, Northern Jutland is indicated in Fig. 1 and in Tables 1 and 2 (where thicknesses are omitted it is because they are uncertain).

The Upper Paleocene and Eocene stratigraphic record in Denmark is very similar to that of the Danish Sector of the North Sea (Nielsen, 1980; Zhang, 1986). The Danish outcrops therefore provide an opportunity to examine visually these sediments which are generally only available as cuttings samples from North Sea wells.

Heilmann-Clausen et al. (1984) have investigated the lithology and lithostratigraphy of the Upper Paleocene and Eocene sediments from Denmark, including a description and discussion of clay mineral distribution. All the thicknesses quoted in this paper are taken from Heilmann-Clausen et al. (1984). The Eocene-Paleocene lithostratigraphy at Ølst and Ålbækhoved, Northern Jutland is indicated in Tables 1 and 2; where thicknesses are omitted, it is because they are uncertain. Nielsen (1974) discussed in detail the mineralogy and diagenesis of Lower Eocene clays from Ølst. Other investigations of the Palaeogene clays from Denmark have been made by Unmack (1949), Thiede, Nielsen \& Perch Nielsen (1980), Nielsen (1980), Nielsen \& Heilmann-Clausen (1988). These studies show that these clays are dominated by smectite with subordinate illite and kaolinite. This paper reports for the first time the petrographic character of these clays as observed by electron microscopy. 
Fig. 1 Stratigraphic sections for the sampled intervals at Ølst and Ålbakhoved.

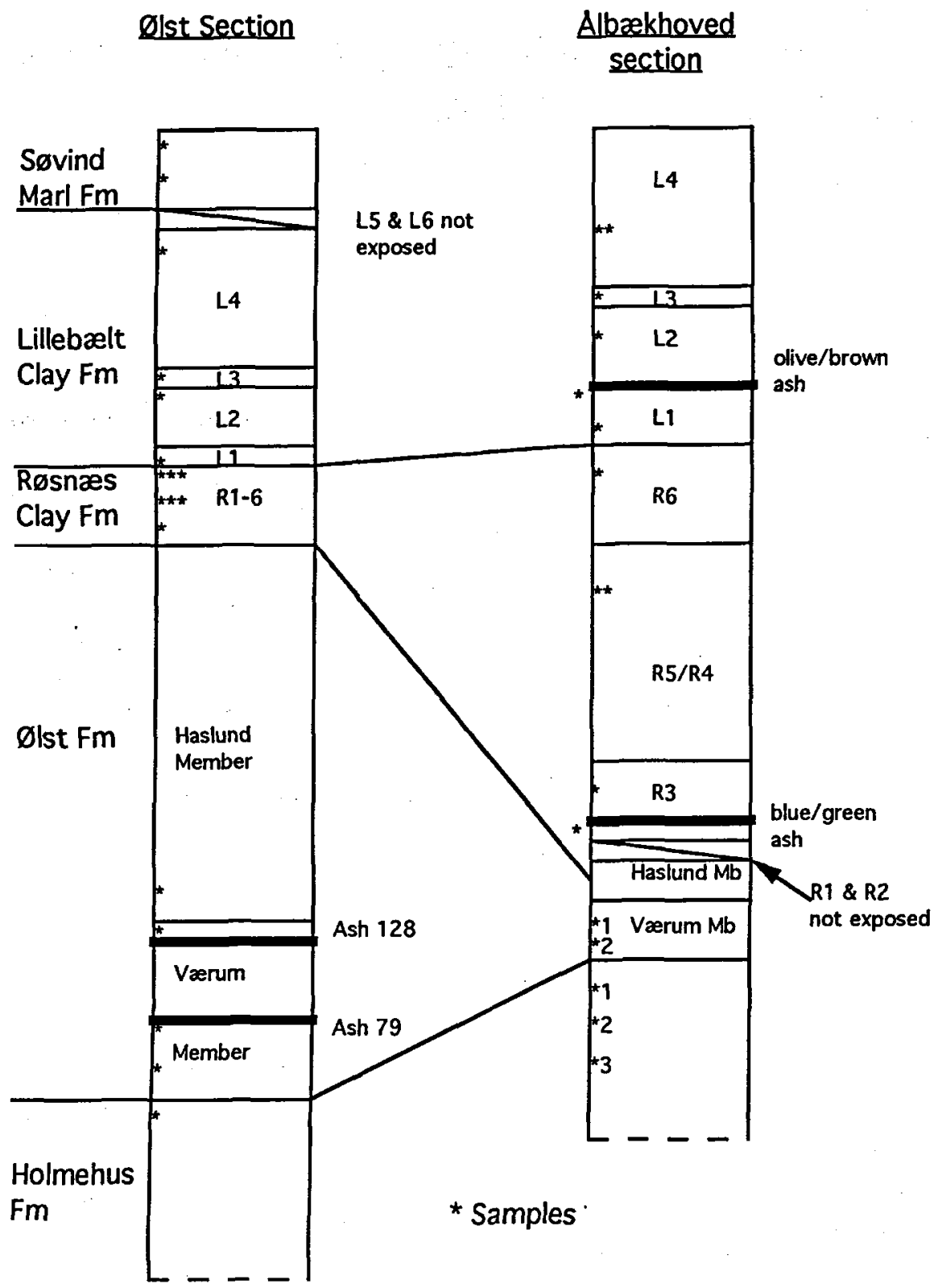

\section{Techniques}

Whole rock and $<2 \mu \mathrm{m}$ clay fraction XRD analyses were carried out on all samples. The clay samples were prepared using a suction onto ceramic tile method (Shaw, 1972). All samples were scanned in a Phillips 1820 automated X-ray diffractometer using $\mathrm{Ni}$-filtered $\mathrm{CuK}$ radiation. The clay tiles were scanned air dried, after saturation with glycol vapour at $60^{\circ} \mathrm{C}$ and after heating at $300^{\circ} \mathrm{C}$ and $550^{\circ} \mathrm{C}$ for 2 hours. A second set of samples were $\mathrm{KCl}$-saturated before scanning to test for the pres- ence of high charge smectite or vermiculite layers. All tiles were scanned at a rate of 5 seconds per 0.02 degrees 2 theta step width, using $0.3 \mathrm{~mm}$ slits from 2 to 40 degrees 2 theta. The whole rock powder samples were scanned at a rate of 15 seconds per 0.15 degrees 2 theta step width with a $5 \mathrm{~mm}$ slit. The powders were scanned from 5 to 65 degrees 2 theta. The mineral estimates (Tables 3 and 4) are probably accurate to + or $-20 \%$ of the amounts actually present. To emphasise this the calculated percentages have been rounded to the nearest $5 \%$, except for values $<5 \%$ and trace $(\mathrm{T})$ minerals. This estimate of accuracy is based on the variations measured in 


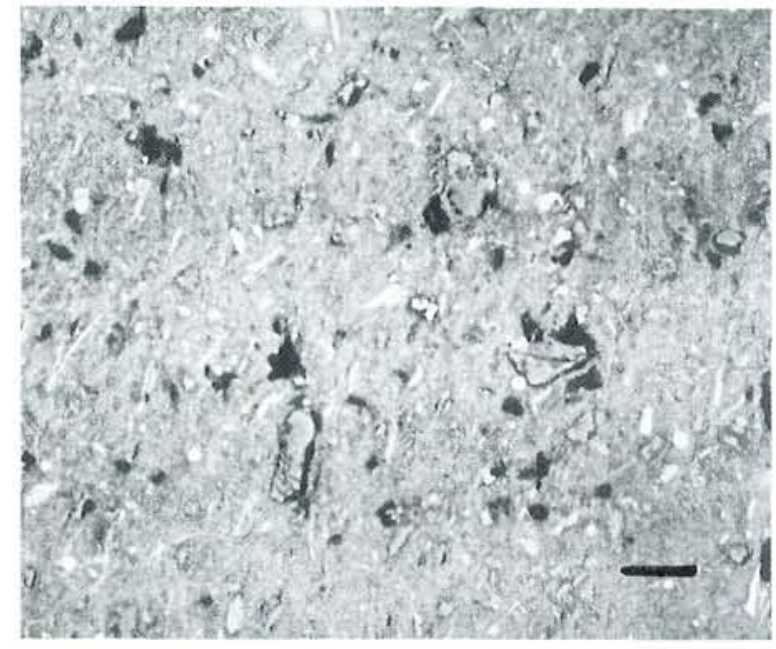

Fig. 2. Holmehus Formation (H2) from Ålbakhoved. Smectite dominated claystone. The small bright particles are pyrite and $\mathrm{TiO}_{2}$. Scale bar $=100 \mu \mathrm{m}$.

simulated known mineral mixtures. Peak weightings for quantification were derived by measuring known mixtures of powder standards for the whole rock analyses and weighed mixtures of pure clays extracted from mudrocks for the clay fraction. Semi-quantitative XRD abundances were calculated using the method of Schultz (1964) modified for the Phillips 1820 system. However it should be noted that the analyses do not include estimates of abundances of volcanic glass or organic matter because they are non-crystalline. Nor are cristobalite, zeolites, $\mathrm{Ti}$ or Fe oxides or apatite included because no peak-weightings are available for these minor components. However if they were detected this is indicated in Tables 3 and 4 . The proportions of non-clay minerals were checked against visual estimates of grains in backscattered scanning electron micrographs (BSEM).

SEM samples for petrological study using backscattered electron imaging (BEI) mode were prepared by gently polishing rock chips which had been impregnated with low viscosity araldite. The polished samples were examined in a Hitachi S2500. Some relief is apparent in the micrographs, because these clays not be polished to give a smooth surface without excessive loss of sample material. This inevitably slightly reduces the accuracy of the quantitative analysis. Quantitative energy dispersive $\mathrm{X}$-ray analyses were carried out using a $2 \mu \mathrm{Amp}$ beam current at $15 \mathrm{Kv}$ accelerating voltage. Many analyses of carbonate minerals (Tables 5-6), clay and silt-size particles were obtained (Table 7). Most clay analyses are contaminated by particles adjacent to the one(s) being analysed because they are smaller than the probe diameter used, and are therefore no better than semi-quantitative. However where a grain has been replaced in situ by clay it may reasonably be assumed that the clay is monomineralic and it is on this basis that the "argillised ash" analyses in Table 7 have been used to determine smectite compositions. Fe II and III cannot be differentiated in EDS analyses, consequently total $\mathrm{Fe}$ only is listed in Table 7. Fe in the carbonates may be assumed to be in the reduced state. Where $\mathrm{S}$ or $\mathrm{Cl}$ coupled with $\mathrm{Na}$ have been detected in an analysis a correction has been made for pyrite or halite respectively.

\section{Petrography}

The detailed petrography of each Formation and the individual members sampled is described in Tables 1 (Ølst) and 2 (Ålbækhoved). The following section summarises the characteristics of each formation.

\section{Holmehus Formation}

The Holmehus Formation (Late Paleocene) is a noncalcareous, green, brown and dark red, very fine-grained clay with very little silt-grade material (Fig. 2). Bedding is indistinct and burrows are present in all horizons. The Holmehus Formation overlies Paleocene clay deposits with silicified beds which have not been formally named (Heilmann-Clausen et al. 1984).

\section{Ølst Formation}

The Ølst Formation (Late Paleocene?) includes the Haslund and Værum Members which are approximately equivalent to the Sele and Balder Formations of the North Sea (Heilmann-Clausen et al. 1984). It overlies the Holmehus Formation and is overlain by the Røsnæs Forma-

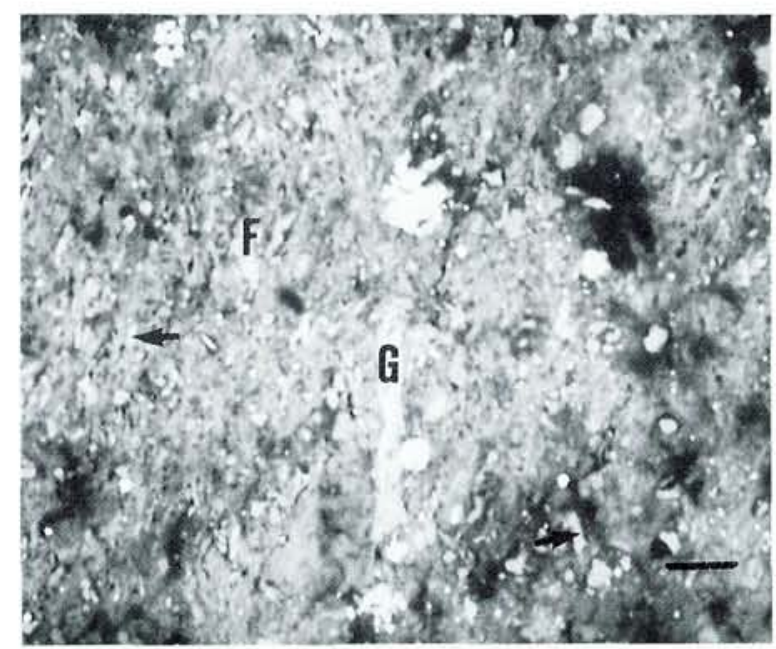

Fig. 3. Ølst Formation (Haslund Member) from Ølst. Smectite dominated claystone with elongated glass particles (G). Arrows denote fragments of calcite microfossils. Bright particles are pyrite. $\mathrm{F}=\mathrm{K}$ feldspar. Black areas are holes in the sample resulting from sample preparation. Scale bar $=100 \mu \mathrm{m}$. 


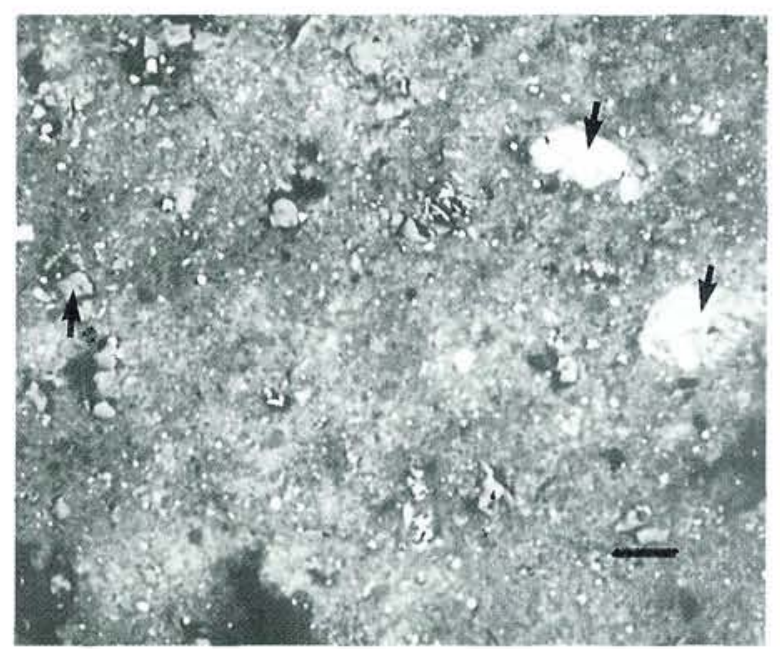

Fig. 4. Ølst Formation (Værum Member) from Ølst. Claystone with abundant smectite and glass (arrows) and sub-ordinate illite. The glass is of two types: Si-rich (dark grey) and Si-poor (white-pale grey). See Table 7 for glass analyses (analysis numbers $2 \& 3$ ). Scale bar $=100 \mu \mathrm{m}$.

tion. The Haslund Member consists of a parallel laminated greyish to olive-black clay interbedded with a few volcanic ash layers, mostly $<1 \mathrm{~mm}$ thick (Fig. 3). The sample analysed for this study contains $20 \%$ microfossil fragments and less glass than any of the Værum Member samples. At Albækhoved the Haslund Member is missing from the section. The Værum Member consists of clays interbedded with volcanic ash beds. The ash beds amount

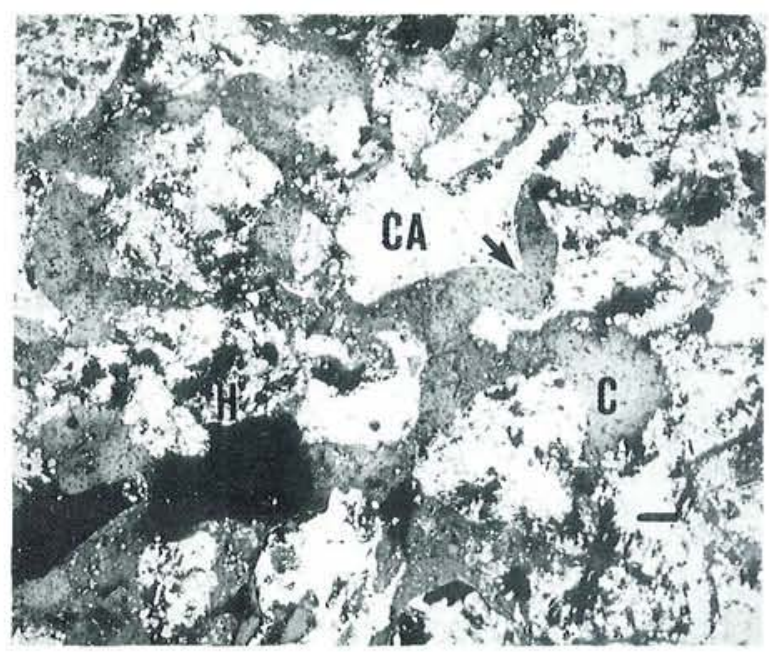

Fig. 5. ØIst Formation (Værum Member) from Ølst. Ash partially altered to clay $(\mathrm{C})$ and heulandite-clinoptilolite $(\mathrm{H})$. Precise identification of the zeolite was not possible because it is intergrown with authigenic calcite. Many particles are lined with a $\mathrm{TiO}_{2}$ (anatase?) cement (arrow). Subsequently the interparticle space has been cemented by calcite (CA. see Table 5 for analysis). Black areas are holes in the specimen resulting from sample preparation. Scale bar $=100 \mu \mathrm{m}$.

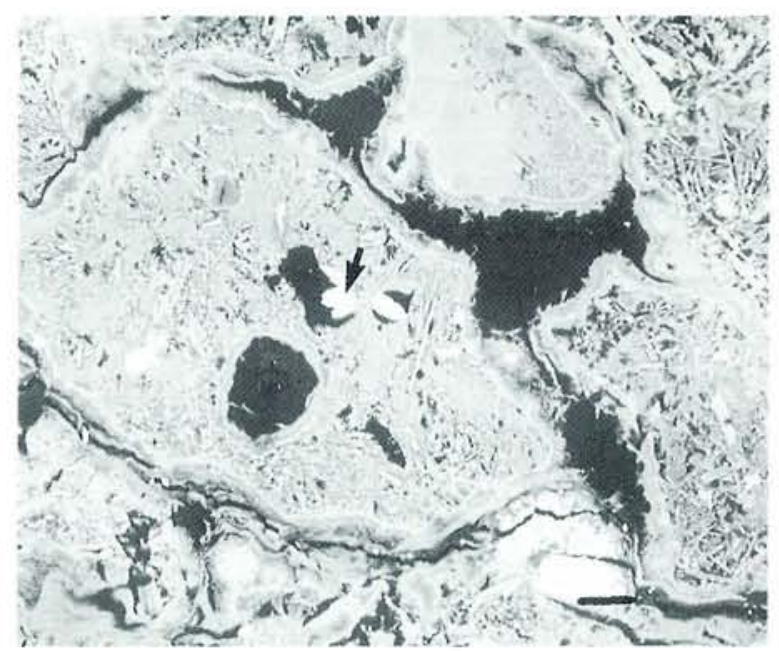

Fig. 6. Ølst Formation (Værum Member) from Ålbækhoved. Ash (Table 7) partly devitrified to feldspars. Analyses are consistent with the clusters of needles being $\mathrm{K}$ feldspar (Table 7 ). Manganoan siderite crystals (white) have formed in vesicles in the glass particles (black holes) and as an internal cement in some devitrified particles (arrow). Scale bar $=100 \mu \mathrm{m}$.

to almost half the thickness of the member. Silt-grade glass (Figs 3 and 4 ) is more abundant in the Ølst Clay than in any of the other formations sampled. The remainder of the silt fraction consists of rare quartz and plagioclase. The glass in the ash beds has been extensively replaced by authigenic smectite, carbonates, and to a lesser extent, pyrite, Ti oxide and zeolites (Figs 5-6) and In ashes number 1 and 79 (Heilmann-Clausen et al. 1984)

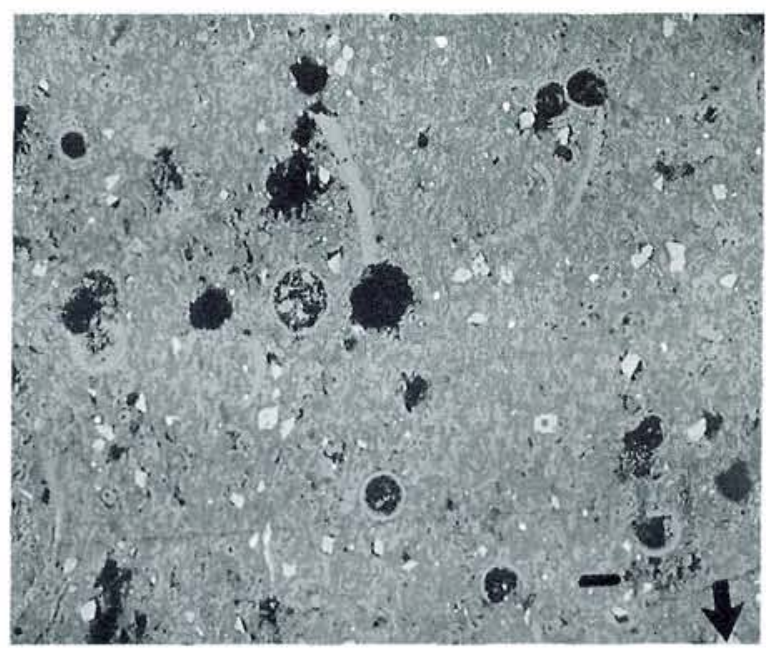

Fig. 7. Røsnæs Clay Formation (R3 bed) from Ålbrkhoved. Smectite dominated claystone with abundant foraminifera and foraminifera fragments. Many of the foraminifera have been leached leaving circular holes, none have internal cement. Rhombs of calcian rhodochrosite (e.g. arrow) have nucleated onto rounded cores of mixed carbonate composition. Scale bar $=$ $100 \mu \mathrm{m}$. 
Table 1a. Data for the Søvind Marl and Lillebæelt Formation samples from Ølst.

\begin{tabular}{|c|c|c|c|c|}
\hline Age & Formation & $\begin{array}{l}\text { Bed/ Lithology } \\
\text { Member }\end{array}$ & Detrital & Authigenic minerals \\
\hline
\end{tabular}

Eocene Søvind Marl

Lillebælt

L4

L3 claystone with yellow bioturbated layers. $1.2 \mathrm{~m}$ thick

The lower $3 \mathrm{~m}$ are green, non-calcareous, extremely fine-grained clay, whilst in the upper $5 \mathrm{~m}$ green and brown beds alternate. The sample is from the green bed

Dark-green carbonate-rich horizon overlain by greygreen carbonate-poor total

Grey-green, non-calcareous claystone with small black streaks and a few beds rich in organic matter. $2.7 \mathrm{~m}$ thick

L1

Red-brown non-calcareous
Red-brown, non-calcareous

The carbonate-rich horizon $\mu \mathrm{m})$, though a few andesine clay with 3 thin ash horizons. $0.9 \mathrm{~m}$ thick. The sample described here is from between the upper green ash and the 2 lower ashes contains $20 \%$ low Mg calcite microfossil bioclasts. The clastic fraction in both horizons is mostly smectite, plus illite, kaolinite. $10 \%$ silt comprising quartz, glass, albite and rare $\mathrm{K}$ spar, TiFe oxides and phengite

Mostly smectite, plus about $5 \%$ each of silt-grade quartz, plagioclase (andesine and albite), $\mathrm{K}$ feldspar and rare glass. Most grains are fine to medium silt-grade (10-20 grains are up to $100 \mu \mathrm{m}$. Mostly bioturbated fabric

Mostly smecite, minor illite, kaolinite plus $<10 \%$ total silt grade quartz, albite and volcanic glass. The volcanic glass is typically rich in $\mathrm{Al}$, $\mathrm{Si}, \mathrm{Fe} \& \mathrm{Na}$ (Fig. 15). Random bioturbated fabric

Mostly smectite (Table 7 for analysis), minor illite, glaucony and kaolinite. $<10 \%$ silt-grade quartz, rare glass, $K$ spar, plagioclase and apatite. Bioturbated fabric

Rare Mn siderite $(<10 \mu \mathrm{m})$ and pyrite in the carbonatepoor horizon. Minor ragged siderite rhombs $(10-20 \mu \mathrm{m})$ (Table 5 for analyses), calcite rhombs $(<6 \mu \mathrm{m})$ and rare pyrite in the carbonate-rich horizon

Calcite concretions (typically $2 \mathrm{~mm}$ across) with trace $\mathrm{Fe}$ substitution only. The calcite has extensively replaced clastic material and encloses rare pyrite framboids. Fecal pellets have been cemented by micritic calcite (Table 5 for analysis, Fig. 16)

Calcian rhodochrosite (Table 5 for analysis) is a minor cement, particularly in the yellow claystone. The calcian rhodochrosite crystals are typically 4-8 $\mu \mathrm{m}$ and have nucleated on to clastic material. Rare pyrite present

Minor smectite pseudomorphs of grains (glass?)

Mostly smectite, minor illite and kaolinite. $<10 \%$ clay-grade and calcain rhodochrosite quartz and $\mathrm{K}$ spar. Partially bioturbated, with fecal pellets (Table 5 for analysis) from Ølst, minor barytes is present. The clay fraction of both the ash and clay beds is dominated by smectite, with variable proportions of illite and rare kaolinite (Tables 3 and 4).

\section{Røsnæs Clay Formation}

The Røsnæs Clay Formation (Early Eocene) overlies the $\varnothing$ lst Formation and is overlain by the Lillebælt Clay Formation (Heilmann-Clausen et al. 1984). It is subdivided into 7 beds, of which 6 are present at $\emptyset 1$ st. At the time of sampling bed R2 was not exposed at Ølst. Neither R1 or R2 could be sampled at Ålbækhoved. At Ølst the Røsnæes Clay Formation is only $3.2 \mathrm{~m}$, compared with 18 $\mathrm{m}$ at Ålbækhoved. Bioturbation has occurred throughout the Røsnæs Clay Formation (e.g. Figs 7 \& 12) and Zoophycos burrows are common. The Røsnæs Clay Formation is variably coloured, reflecting the varying proportions of organic matter, iron oxides and glaucony. The clastic silt-fraction is typically $<10 \%$ and consists mainly of quartz and albite, the carbonate silt fraction consists of microfossil fragments (Figs 7-12). At Ølst the clay mineralogy is dominated by smectite (Table 3), at Ålbækhoved illite and kaolinite make up a higher proportion of the clay fraction (Table 4). $\mathrm{Mn}$ and Ca carbonate cements are common, particularly at $\emptyset 1 s t$, whilst at Ålbakhoved bioclastic detritus is more abundant than authigenic carbonates. 
Table 1b. Data for the Røsnæs Clay, Ølst and Holmehus Formation samples from Ølst.

\begin{tabular}{llll}
\hline Age & Formation & $\begin{array}{l}\text { Bed/ } \\
\text { Member }\end{array}$ & Lithology \\
\hline Eocene & Røsnæs & R6 & $\begin{array}{l}\text { Light greenish calcareous, } \\
\text { parallel laminated claystone } \\
\text { with a black bioturbated } \\
\text { horizon in the middle of the } \\
\text { bed. Zoophycos burrows } \\
\text { penetrate both lithologies. } \\
40 \text { cm thick }\end{array}$ \\
& &
\end{tabular}

R5 Light reddish-brown, highly calcareous claystone.

Carbonate cemented

zoophycos are common

R4 Dark reddish-brown, slightly calcareous clay showing an upward increase in carbonate content. Six green to dark green ash beds (2-3 cm thick) are present but were not sampled. $105 \mathrm{~cm}$ thick

R3 Yellowish-brown, slightly calcareous, bioturbated mudstone. R3 generally has a high proportion of sand grains, but this sample is a claystone. $30 \mathrm{~cm}$

R2 Not exposed

R1 Green, non-calcareous claystone which has been thoroughly bioturbated. $35 \mathrm{~cm}$ thick

Paleocene $\varnothing \mathrm{lst}$

Varum $\mathrm{mb}$

Dark grey ash bed (No. 128) from the top of the member

Green-grey, non-calcareous claystone interbedded with ash beds which form almost half the total thickness of $9.1 \mathrm{~m}$. The sample is from above ash bed 79

Light grey ash bed from below the claystone sample (Table 7 for analyses of silt-grade glass \& ash)

Haslund Grey to olive-black parallel $\mathrm{mb}$ laminated claystone interbedded with a few volcanic ash layers, mostly $<1 \mathrm{~mm}$ thick. $20 \mathrm{~m}$ total thickness

Holmehus claystone. Bedding is
Detrital

Mostly smectite and calcite, plus illite, $<10 \%$ total very fine siltgrade quartz, glass, albite and $\mathrm{K}$ feldspar (Fig. 11). The calcite consists of microfossils and irregularly shaped bioclasts. The green and organic-rich intervals have the same mineralogy

Mineralogically very similar to $\mathrm{R} 4$ except for the presence of abundant fragments of microfossils

Mostly smectite, plus illite, $<10 \%$ total silt-size quartz, glass, albite, rare kaolinite, Ti/Fe oxides \& calcite microfossils

Mostly smectite, plus hydrated silt-size glass, <5\% total quartz, $\mathrm{K}$ spar and albite, rare illite, kaolinite, apatite and organic matter

Mostly smectite, plus illite, glaucony, very altered silt-size glass $\&$ rare quartz, albite, andesine and $\mathrm{K}$ spar. The andesine \& $\mathrm{K}$ spar are extensively leached

Mostly highly altered and compacted glass particles. Interstital illite, smectite, rare quartz \& plagioclase are probably detrital

Mostly smectite, plus volcanic glass, illite, minor albite \& trace quartz (Fig. 4). Glass is present in 2 forms: low \& high $\mathrm{Si}$ in proportion to total cations (Table 7)

Mostly glass \& smectite?, plus minor quartz, plagioclase, trace illite \& kaolinite

The clastic mineralogy of the claystone is mostly smectite, plus illite \& kaolinite, $\mathrm{K}$ spar, elongate glass fragments \& heulandite (Fig. 3). Very fine silt-grade calcite microfossil fragments are abundant

Mostly smectite, plus glaucony, minor quartz, feldspars, calcite \& glass, rare kaolinite, $\mathrm{Ti}$ oxide and pyrite. Thoroughly bioturbated
Authigenic minerals

Rare rhombs of Calcian rhodochrosite which have nucleated onto rounded (therefore either detrital or corroded authigenic) high $\mathrm{Mg}$ calcite grains (Table 5 for analyses). Glaucony?

Carbonate with similar composition to the microfossils ( $<5 \%$ total Fe \& $\mathrm{Mg}$ ) is present as cement inside the few still whole fossil tests. Calcian rhodochrosite is present as discrete rhombs scattered through the matrix (Table 5 for analysis)

Rhombs of Mn calcite with overgrowths of calcian rhodochrosite (Table 5 for analyses, Fig. 8)

Minor calcite is present, but as it was not observed it is not possible to identify its origin

Glaucony?

Many glass particles are replaced by heulandite-clinoptilolite intergrown with calcite. Calcite cement (Table 5) has locally replaced ash \& cemented interparticle space (Fig. 5). Between the glass and calcite there is often a rim of TiO2 (anatase?)

Cristobalite?

Extensive replacement by smectite \& calcite. A few particles have rims of pyrite. Local anhydrite \& heulandite cements surround the earlier pyrite. This bed is bordered by $\mathrm{Ba}$ SO 4 cement above \& below

Glaucony?

\section{Rare pyrite framboids} indistinct \& burrows are visible. Thickness uncertain 
Table 2a. Data for the Lillebælt Formation samples from Ålbækhoved.

\begin{tabular}{|c|c|c|c|c|c|}
\hline Age & Formation & $\begin{array}{l}\text { Bed/ } \\
\text { Member }\end{array}$ & Lithology & Detrital & Authigenic minerals \\
\hline \multirow[t]{6}{*}{ Eocene } & Lillebælt & L4 & $\begin{array}{l}\text { Only the lower green } \\
\text { clay is exposed. } \\
\text { Concretions and } \\
\text { carbonate cemented } \\
\text { burrows are present. } \\
>8 \mathrm{~m} \text { thick }\end{array}$ & $\begin{array}{l}\text { Mostly smectite \& glaucony, but a } \\
\text { higher proportion of illite \& } \\
\text { kaolinite than at } \emptyset \text { lst. Silt grains } \\
\text { are }<4 \mu \mathrm{m}, \text { smaller than at } \emptyset l s t \\
\text { and almost entirely quartz \& glass. } \\
\text { The glass is } \mathrm{Al}, \mathrm{Si} \text {, Fe, Na rich \& } \\
\text { partially hydrated. Thoroughly } \\
\text { bioturbated }\end{array}$ & $\begin{array}{l}\text { Rare aggregates of pyrite } \\
\text { (Fig. 17) }\end{array}$ \\
\hline & & & $\begin{array}{l}\text { Carbonate cemented } \\
\text { burrow from the above } \\
\text { sample }\end{array}$ & $\begin{array}{l}\text { About } 50 \% \text { of the cemented } \\
\text { burrow wall \& } 75 \% \text { of the burrow } \\
\text { fill is clay dominated clastic } \\
\text { material. Smectite is relatively less } \\
\text { abundant than the surrounding } \\
\text { green clay }\end{array}$ & $\begin{array}{l}\text { The burrow wall is cemented } \\
\text { by micritic mixed carbonate } \\
\text { (Table 6). Coarser crystals of } \\
\text { compositionally identical } \\
\text { carbonate cement \& pyrite } \\
\text { infill microfossil tests } \\
\text { (Fig. 18). The burrow fill is } \\
\text { cemented by calcian rho- } \\
\text { dochrosite (Table 6, Fig. 19) }\end{array}$ \\
\hline & & L3 & $\begin{array}{l}\text { Red-brown, non- } \\
\text { calcareous claystone. } \\
0.7 \text { m thick }\end{array}$ & $\begin{array}{l}\text { Mostly smectite, minor illite, } \\
\text { kaolinite plus <10\% total silt } \\
\text { grade quartz, albite \& volcanic } \\
\text { glass. Preferred orientation of } \\
\text { micas indicates that this bed has } \\
\text { not been bioturbated }\end{array}$ & Rare pyrite \\
\hline & & $\mathrm{L} 2$ & $\begin{array}{l}\text { Grey-green, non- } \\
\text { calcareous clay with a } \\
\text { few organic-rich beds. } \\
\text { This sample was } \\
\text { obtained from one of } \\
\text { the organic-rich beds. } \\
3.5 \text { m thick }\end{array}$ & $\begin{array}{l}\text { Mica flakes indicate a semi- } \\
\text { random orientation, resulting from } \\
\text { partial bioturbation. Organic } \\
\text { matter occurs as irregularly shaped } \\
\text { pods }<100 \mu \mathrm{m} \text { long }\end{array}$ & Rare clay-grade pyrite \\
\hline & . & L1 & $\begin{array}{l}\text { Dark olive brown, } \\
\text { altered ash between } \\
\text { L1 \& L2. Parallel } \\
\text { laminated }\end{array}$ & $\begin{array}{l}\text { Mostly smectite, plus illite, } \\
\text { kaolinite \& } 5 \% \text { silt-grade quartz, } \\
\text { rare K spar \& leached grains of } \\
\text { Ti oxide. The low XRD total } \\
\text { (Table } 3 \text { ) may indicate the } \\
\text { presence of significant amounts of } \\
\text { clay-grade volcanic glass }\end{array}$ & Rare pyrite (Fig. 13) \\
\hline & & & $\begin{array}{l}\text { Dark brown, non- } \\
\text { calcareous clay. } 3.05 \mathrm{~m} \\
\text { thick }\end{array}$ & $\begin{array}{l}\text { Mostly smectite, plus illite, } \\
\text { kaolinite \& } 10 \% \text { fine silt-grade } \\
\text { quartz \& albite, rare Al, Si, Fe, } \\
\text { Na-rich glass \& phengite }\end{array}$ & Rare pyrite \\
\hline
\end{tabular}

\section{Lillebælt Clay Formation}

The Lillebælt Clay Formation (Early? to Middle Eocene) overlies the Røsnæs Clay Formation and is overlain by the Søvind Marl Formation (Heilmann-Clausen et al. 1984). Six distinct lithological units are present in the Lillebælt Clay Formation, of which L1 to L4 were sampled (L5 and L6 were not unequivocally exposed at the time of sampling). The Lillebælt Clay (Figs 13-19) is dominated by smectite, particularly at Ølst, other clays present are illite and kaolinite. The silt fraction is typically $5-10 \%$, and consists of quartz, plagioclase (mostly albite) and $\mathrm{K}$ feldspar (Tables 3 and 4). The Lillebælt
Clay includes various concretions and micrite-sized carbonate cements (e.g. Figs 18-19) in all beds except L2. Mixedcarbonate and phosphatic concretions are particularly common, though none were sampled for this study.

\section{Søvind Marl Formation}

The Søvind Marl Formation consists of a bioclast-rich horizon overlain by a carbonate-poor horizon. It contains a slightly higher silt fraction than the other formations sampled (Table 1). Significant microporosity has been preserved in association with the bioclasts. The Søvind Marl appears to have a random fabric, suggestive of 
Table 2b. Data for the Røsnæs Clay, Ølst and Holmehus Formation samples from Ålbakhoved.

\begin{tabular}{|c|c|c|c|c|}
\hline Age & Formation & $\begin{array}{l}\text { Bed/ } \\
\text { Member }\end{array}$ & Lithology & Detrital \\
\hline \multirow[t]{3}{*}{ Eocene } & Røsnæs & R6 & $\begin{array}{l}\text { Red-brown, calcareous } \\
\text { claystone sampled from } \\
\text { the middle of R6. } \\
\text { Partially bioturbated. } \\
5.6 \text { m thick maximum }\end{array}$ & $\begin{array}{l}\text { Approximately } 50 \% \text { calcite } \\
\text { microfossil bioclasts, } 50 \% \\
\text { clastic minerals of which } \\
\text { about half is smectite. Illite, } \\
\text { kaolinite \& rare silt-grade } \\
\text { quartz \& K spar are also } \\
\text { present }\end{array}$ \\
\hline & & R5 & $\begin{array}{l}\text { Light reddish-brown, } \\
\text { highly calcareous } \\
\text { claystone. Carbonate } \\
\text { cemented zoophycos are } \\
\text { common. R5 \& R4 total } \\
12.9 \mathrm{~m}\end{array}$ & $\begin{array}{l}\text { Approximately } 40 \% \text { calcite } \\
\text { microfossil bioclasts, } 50 \% \\
\text { clay of which most is } \\
\text { smectite, the remainder illite } \\
\& \text { kaolinite. Silt-size grains } \\
\text { are rare, only quartz \& } \\
\text { kaolinite pseudomorphs after } \\
\text { mica were observed (Fig. } 10 \text { ) }\end{array}$ \\
\hline & & $\begin{array}{l}\text { R3 } \\
\text { equivalent }\end{array}$ & $\begin{array}{l}\text { Orange-brown, calcarous, } \\
\text { bioturbated claystone }\end{array}$ & $\begin{array}{l}\text { Mostly smectite, with minor } \\
\text { illite \& kaolinite. The silt } \\
\text { fraction consists almost } \\
\text { entirely of foraminifera tests } \\
\text { \& other bioclastic fragments. } \\
\text { Most foraminifera have been } \\
\text { leached leaving spherical } \\
\text { moldic pores (Fig. } 7 \text { ) }\end{array}$ \\
\hline
\end{tabular}

R3 Blue-green ash with a Mostly smectite, plus illite, equivalent random, bioturbated fabric glaucony \& kaolinite. This ash has a higher \% silt-size quartz, K spar \& albite, which suggests that it is not a pure ash fall. Rare siltgrade glass, mica \& apatite are also present

$\begin{array}{lll}\text { Paleocene } \varnothing l s t & \begin{array}{l}\text { Værum } \\ \text { mb } 2\end{array} & \begin{array}{l}\text { Olive-grey ash }>2.1 \mathrm{~m} \\ \text { thick }\end{array}\end{array}$

Holmehus H1 Green, non-calcareous claystone. Bedding is indistinct \& burrows are visible

$\mathrm{H} 2$

Red, non-calcareous claystone. Bedding is indistinct $\&$ burrows are

The entire bed consists of chemically altered, but morphologically distinct ash particles. Kaolinite, illite \& phenocrysts of K spar are probably primary. The rims of the ash particles have a composition which may be glass (Table 7 for analyses)

Mostly glaucony \& smectite with minor illite, quartz, albite, glass \& rare kaolinite

Smectite, with minor quartz, albite, glass \& rare kaolinite

No clear evidence of authigenesis, though much of the clay (smectite \& glaucony?) may be authigenic

Minor rhombs of calcian rhodochrosite have nucleated on rounded carbonate grains of mixed cation composition (Table 6 for analyses)

Minor rhombs of calcian rhodochrosite have nucleated on rounded carbonate grains of mixed composition (Table 6 for analyses)

Fibrous aggregates of $\mathrm{K}$ spar (\& smectite?) are the main alteration products (Fig. 6). A few ash particles have been replaced by $\mathrm{Mn}$ - or $\mathrm{Ca}$-rich siderite \& rare heulandite. Cristobalite (detected by XRD only) is probably also authigenic

"Ghost" outlines of former grains now replaced by smectite imply that widespread replacement (of glass?) by clay has occurred. Rare pyrite

"Ghost" outlines of former grains now replaced by smectite imply that widespread replacement (of glass?) by clay has occurred (Fig. 2, Table 6 for analysis). Rare pyrite

H3 Grey, non-calcareous claystone. Bedding is indistinct \& burrows are visible

Mostly smectite, with minor illite, quartz, albite, glass \& rare kaolinite
"Ghost" outlines of former grains now replaced by smectite imply that widespread replacement (of glass?) by clay has occurred (Fig. 2, Table 6 for analysis). Rare pyrite 
Table 3. Semi-quantitative XRD analyses for Ølst samples. Low totals are principally due to the presence of glass, but also minor oxides, hydroxides, cristobalite and apatite. * Indicates that glauconite is included with other $10 \AA$ phyllosilicates.

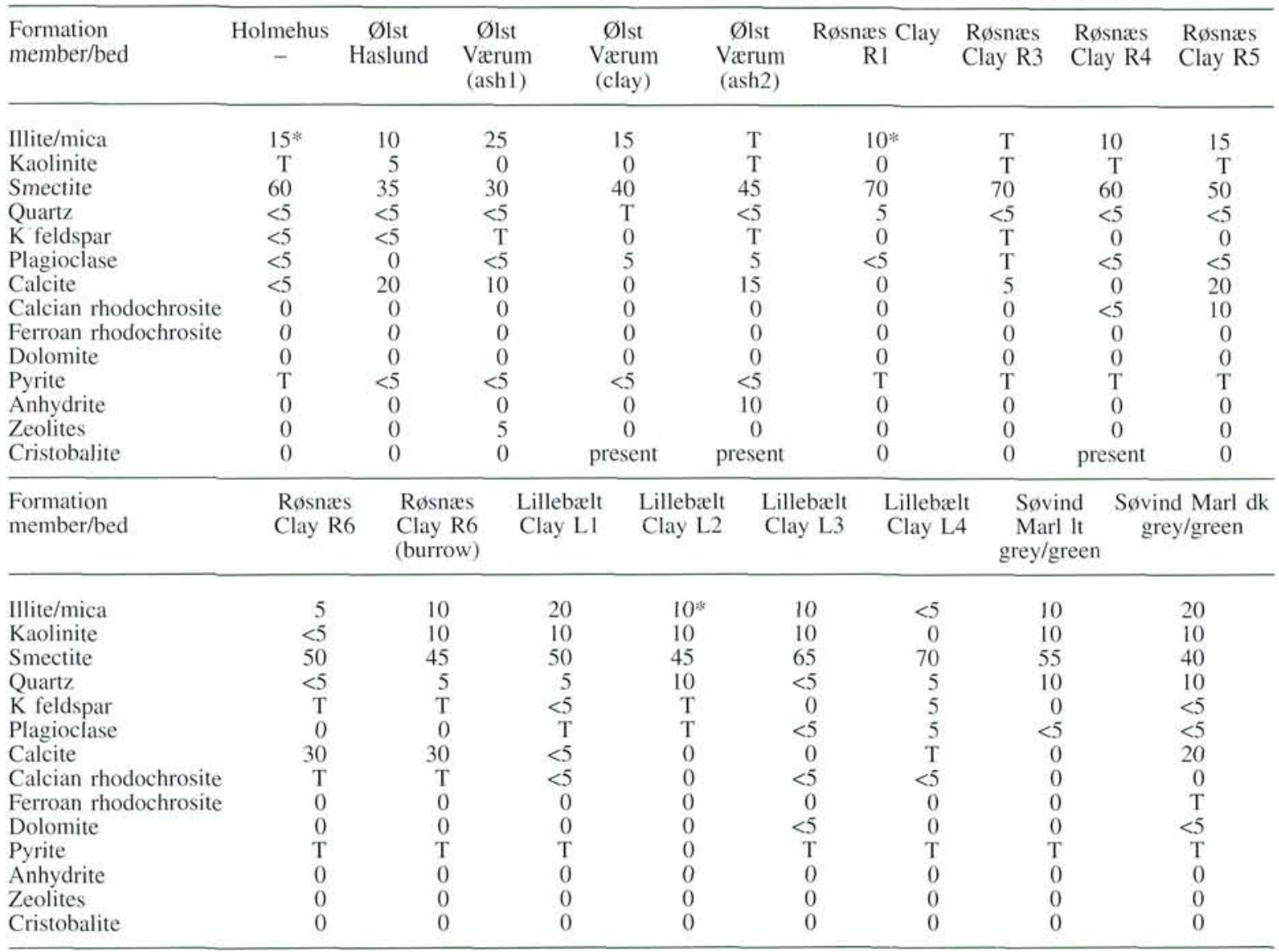

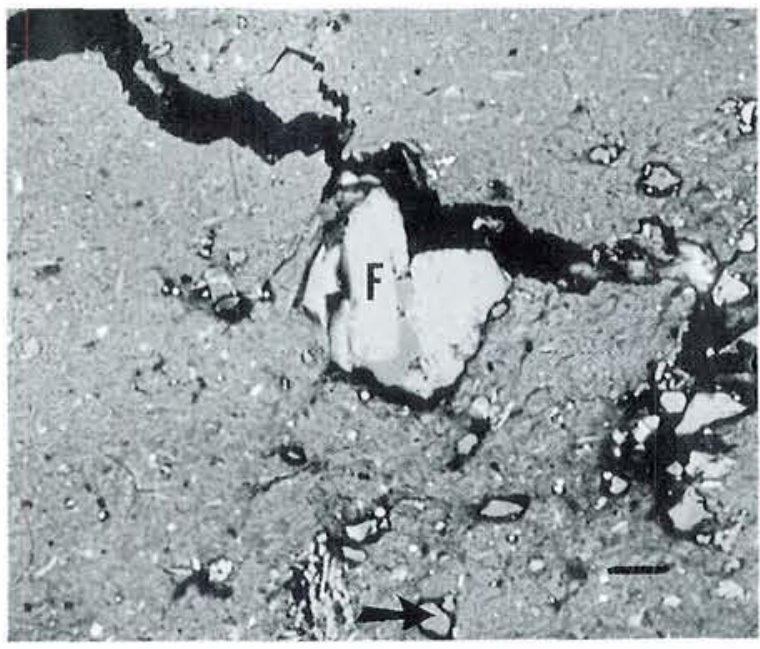

Fig. 8. Røsnæs Clay Formation (R3 ash bed) from Ålbækhoved. This ash horizon has a significant clastic component consisting of feldspars ( $\mathrm{F}=$ albite (dark)/k feldspar (pale) grain), quartz (arrow) and apatite. Clay-grade white particles are mostly TiFe oxide. Black areas are holes and fractures resulting from sample preparation. Scale bar $=100 \mu \mathrm{m}$.

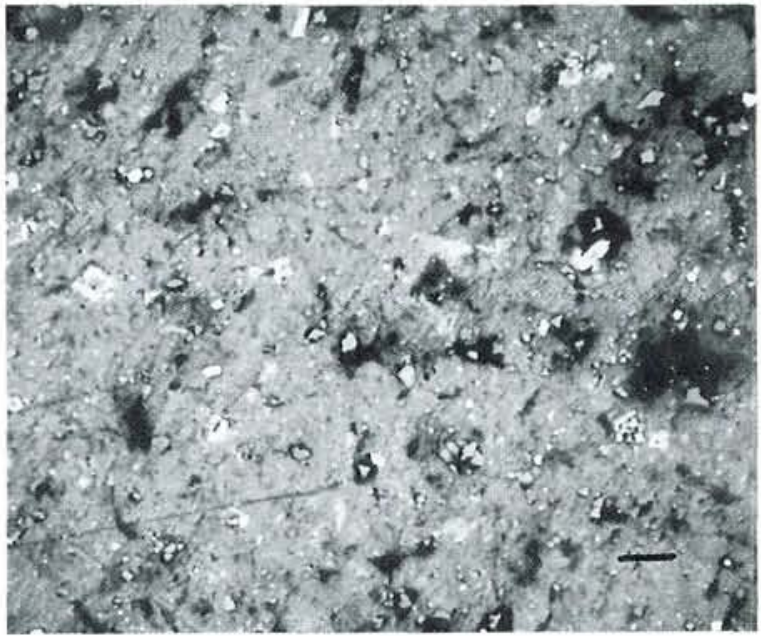

Fig. 9. Røsnæs Clay Formation (R4) from Ølst. Smectite dominated claystone. Rhombs of manganoan calcite have overgrowths of calcian rhodochrosite (arrowed, see Table 5 for analyses). Scale bar $=100 \mu \mathrm{m}$. 
Table 4. Semi-quantitative XRD analyses for Ålbakhoved samples. Low totals are principally due to the presence of glass, but also minor oxides, hydroxides, cristobalite and apatite. * Indicates that glauconite is included with other $10 \AA$ phyllosilicates.

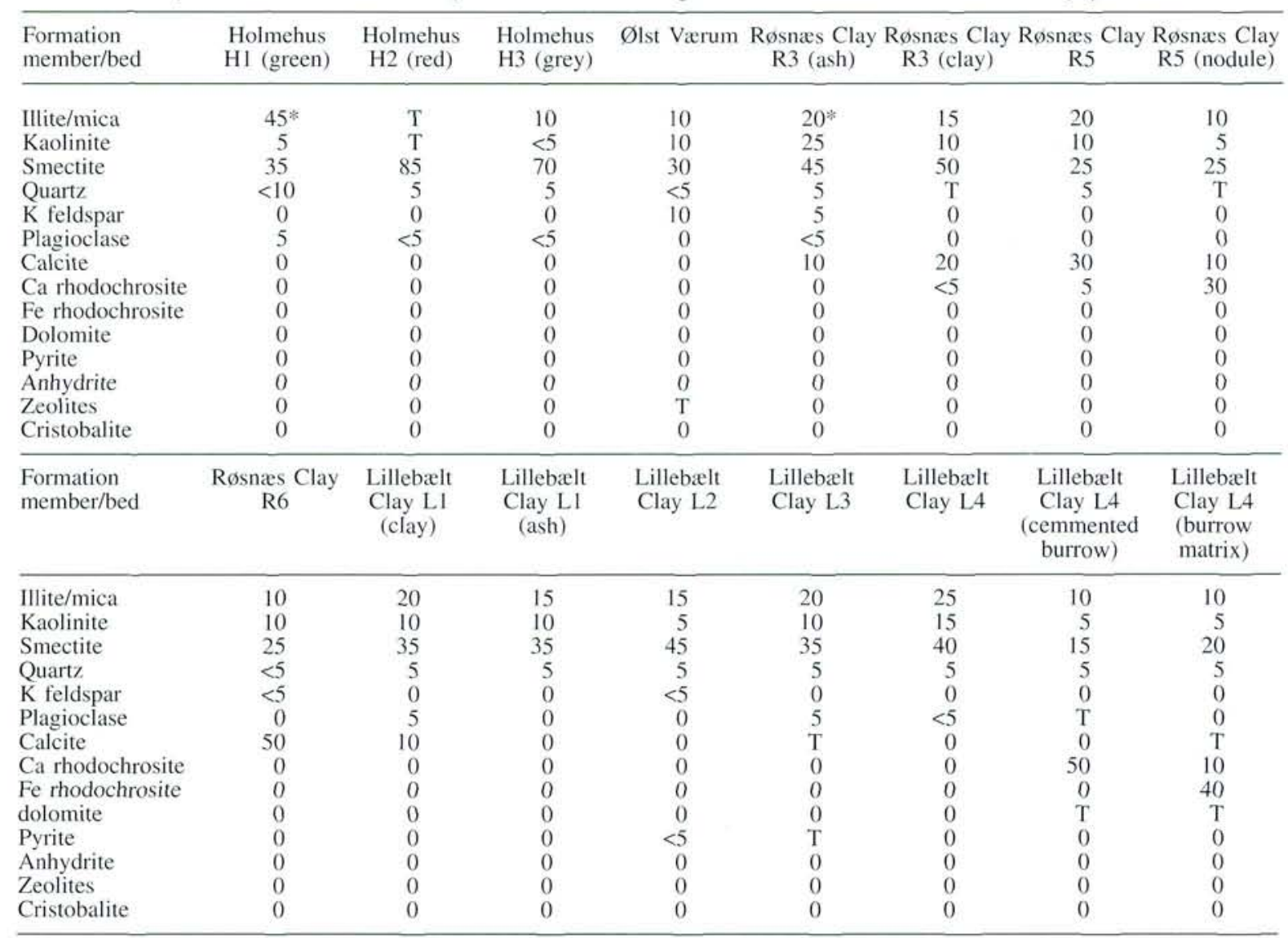

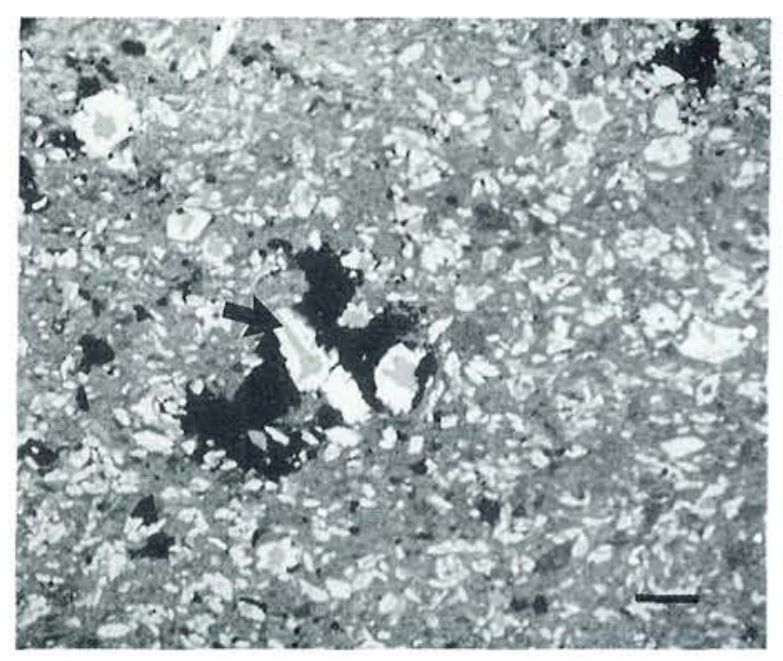

Fig. 10. Røsnas Clay Formation (R5) from Ålbxkhoved. A calcian rhodochrosite cemented zoophycos burrow. The calcian rhodochrosite (arrow) has nucleated on irregularly shaped and rounded low-Mn calcite fragments (grey). Scale bar $=100 \mu \mathrm{m}$.

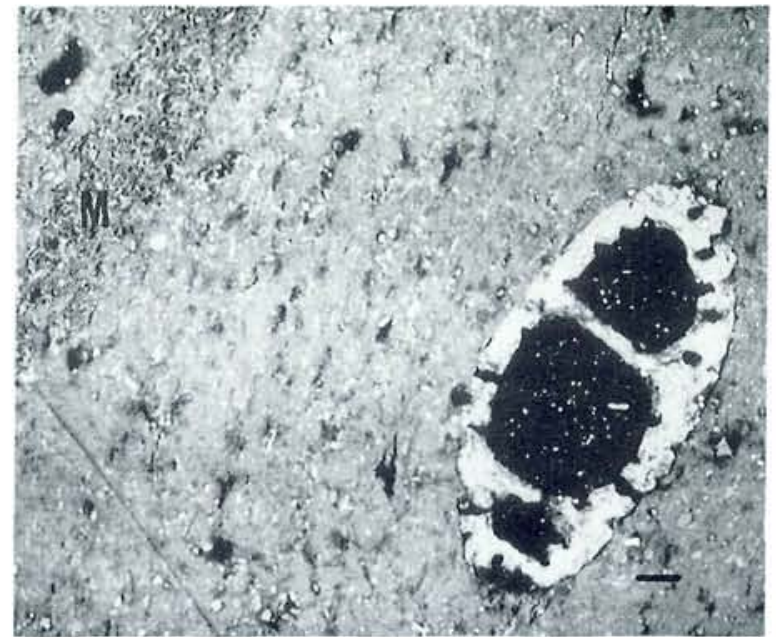

Fig. 11. Røsnæs Clay Formation (R6) from Ølst. Smectite dominated claystone with a $20 \mu \mathrm{m}$ thick laminae consisting almost entirely of microfossil debris (M). Scale bar $=100 \mu \mathrm{m}$. 


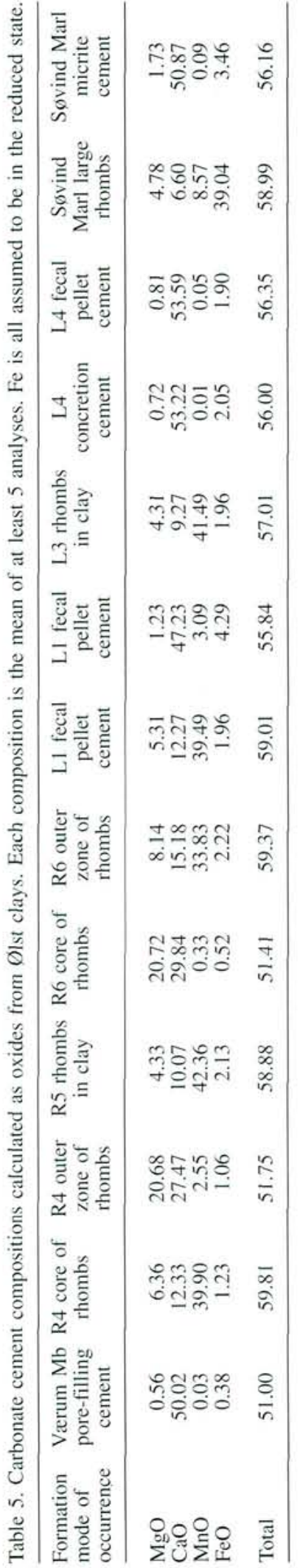

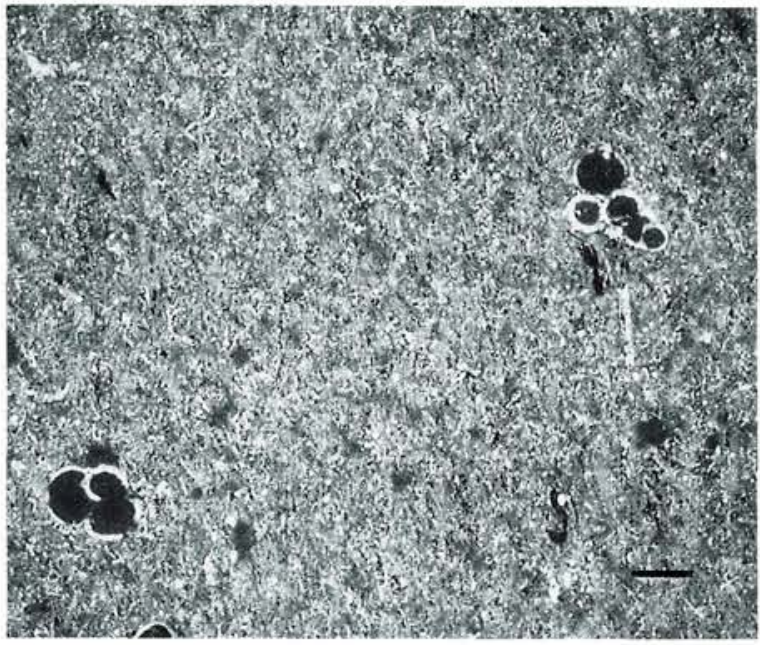

Fig. 12. Røsnæs Clay Formation (R6) from Ålbækhoved. Calcareous claystone consisting of roughly equal parts calcite microfossil debris and clay. Intact microfossils contain no intraparticle cements. The fabric is completely random as a result of bioturbation. Scale bar $=300 \mu \mathrm{m}$.

bioturbation. The clastic fraction is dominated by smectite, with illite, kaolinite and about $10 \%$ silt of which most is quartz (Table 3 ). The only authigenic minerals detected in the carbonate-poor horizon are rare manganoan siderite and pyrite. In the carbonate-rich horizon ragged (reworked or leached?) $10-30 \mu \mathrm{m}$ rhombs of siderite are present (Table 5). Minor authigenic rhombs of calcite $<6 \mu \mathrm{m}$ diameter (Table 5) and rare pyrite are also present in this horizon.

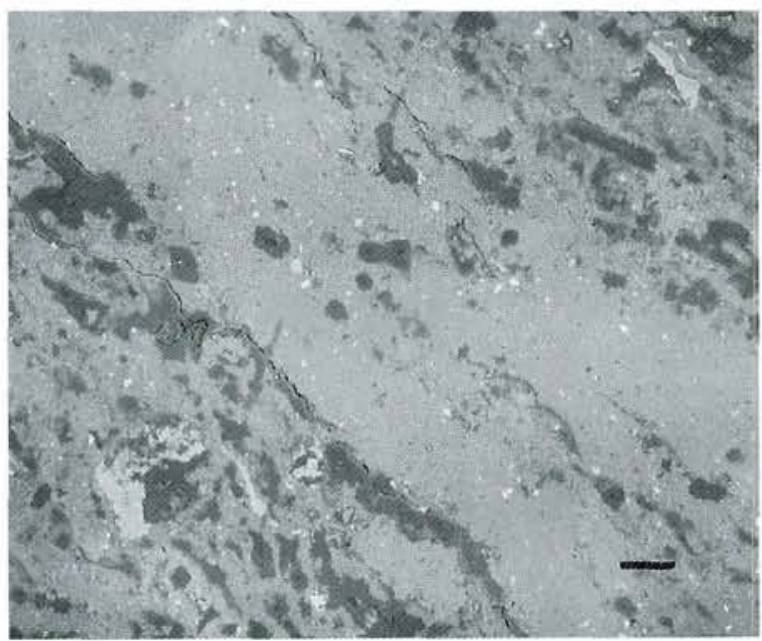

Fig. 13. Lillebælt Clay Formation (L1 ash) from Ålbækhoved. Devitrified ash, with a well developed preferred orientation indicating that this ash has not been bioturbated. The rare pale grey grains are $\mathrm{K}$ feldspar. Scale bar $=300 \mu \mathrm{m}$. 
Table 6. Carbonate cement compositions calculated as oxides from Ålbækhoved clays. Each composition is the mean of at least 5 analyses. Fe is all assumed to be in the reduced state.

\begin{tabular}{lcccrrrr}
\hline $\begin{array}{l}\text { Formation mode } \\
\text { of occurrence }\end{array}$ & $\begin{array}{c}\text { Ølst (V) } \\
\text { replacing glass }\end{array}$ & $\begin{array}{c}\text { R3 rhombs in } \\
\text { clay }\end{array}$ & $\begin{array}{c}\text { R5 core of } \\
\text { rhombs }\end{array}$ & $\begin{array}{c}\text { R5 outer zone of } \\
\text { rhombs }\end{array}$ & $\begin{array}{c}\text { L4 concretion } \\
\text { cement }\end{array}$ & $\begin{array}{c}\text { L4 burrow-fill } \\
\text { cement }\end{array}$ \\
\hline $\mathrm{MgO}$ & 3.67 & 4.31 & 0.28 & 7.77 & 5.66 & 4.29 \\
$\mathrm{CaO}$ & 9.58 & 16.44 & 53.74 & 14.42 & 6.95 & 17.63 \\
$\mathrm{MnO}$ & 18.28 & 34.46 & 2.31 & 35.37 & 12.79 & 34.21 \\
$\mathrm{FeO}$ & 29.11 & 2.26 & 0.18 & 0.52 & 35.08 & 2.51 \\
Total & 60.63 & 57.47 & 56.50 & 58.08 & 60.49 & 58.64 \\
\hline
\end{tabular}

\section{Discussion of Diagenesis}

\section{Authigenic carbonates}

Visual estimates based on BSEM observations suggest that carbonates are the most abundant authigenic minerals in these clay sediments. Three manganese bearing carbonate cements have been identified in all formations sampled at Ølst and Ålbækhoved except the Holmehus Formation: manganoan calcite, calcian rhodochrosite and manganoan siderite (Tables 5 and 6). Calcite with no or negligible $\mathrm{Mn}$ is relatively uncommon in these clays. Manganese-rich carbonate nodules have been reported from a wide range of recent sediment types: pelagic (e.g. Coleman, Fleet \& Donson, 1982), coastal (Manheim, 1961) and freshwater (Calvert \& Price, 1970). The manganese-rich carbonates described here are present chiefly as discrete particles rather than nodules. It is probable that this form of manganese-rich carbonate has previously gone unreported due to its fine grain-size.

The distribution of manganese in near-surface sediments is controlled by oxidation of organic matter with concommitant reduction of $\mathrm{MnO}_{2}$. The resulting $\mathrm{Mn}^{2+}$ is soluble and diffuses up to the oxic zone where it reprecipitates as $\mathrm{MnO}_{2}$ (e.g. Froelich, Klinkhammer, Ben- der, Luedtke, Heath, Cullen, Dauphin, Hammond, Hartman \& Maynard (1979). As a result of this re-precipitation a concentration gradient is set up along which the dissolved $\mathrm{Mn}^{2+}$ diffuses. Where there is a lack of $\mathrm{O}_{2}$, and sufficient organic matter is present that it is not all oxidised by aerobic micro-organisms, the $\mathrm{Mn}^{2+}$ concentration can build up to saturation with rhodochrosite $(\mathrm{Li}$, Bischoff \& Mattieu, 1969; Lynn \& Bonatti, 1965). This is the post-oxic environment of Berner (1981) and ranges in depth from $6 \mathrm{~cm}$ to several metres, depending upon the extent of the oxic zone. The highest concentrations of calcian rhodochrosite in the Danish clays was encountered in fecal pellets (Fig. 16) and burrows (Figs 18 and 19), indicating that these have been important microenvironments for carbonate precipitation in these sediments, possibly due to the higher concentration of organic matter associated with these features. Mineralisation of these features, which would have been formed in the oxic zone, would therefore have occured once they were buried into the post-oxic zone.

For manganese-bearing carbonates to precipitate the dissolved $\mathrm{Mn}^{2+}$ must encounter dissolved $\mathrm{CO}_{2}$. This is virtually inevitable as $\mathrm{CO}_{2}$ is produced by reduction of organic matter in the oxic zone and both the $\mathrm{Mn}$ and Fe reducing zones, e.g. Curtis \& Coleman (1986), Curtis (1987). Rhodochrosite being less soluble than calcite, is

Table 7. X-ray analyses of clastic particles. The low totals indicate volatile components in the ash, glass and argillised glass. ${ }^{*}$ EDS analysis does not distinguish $\mathrm{Fe}^{2+}$ and $\mathrm{Fe}^{3+}$, hence this is total $\mathrm{Fe}$, though published analyses (e.g. Brindley \& Brown, 1980) indicate that it is mostly $\mathrm{Fe}^{3+}$.

\begin{tabular}{|c|c|c|c|c|c|c|c|c|}
\hline $\begin{array}{l}\text { Locality } \\
\text { Formation } \\
\text { Particle type }\end{array}$ & $\begin{array}{l}\text { Albækhoved } \\
\text { Holmehus } \\
\text { argillised } \\
\text { glass }\end{array}$ & $\begin{array}{l}\text { Albækhoved } \\
\text { Ølst (V) } \\
\text { ash }\end{array}$ & $\begin{array}{c}\text { Ølst } \\
\emptyset l s t(V) \\
\text { high Si } \\
\text { glass }\end{array}$ & $\begin{array}{c}\varnothing l s t \\
\varnothing l s t(V) \\
\text { low Si } \\
\text { glass }\end{array}$ & $\begin{array}{l}\text { Albakhoved } \\
\text { Ølst V } \\
\text { rim } S i \\
\text { glass }\end{array}$ & $\begin{array}{l}\text { Albækhoved } \\
\text { Ølst (V) } \\
\text { glass }\end{array}$ & $\begin{array}{l}\text { Albækhoved } \\
\emptyset \text { lst (V) } \\
\text { K feldspar } \\
\text { needles }\end{array}$ & $\begin{array}{c}\emptyset \text { lst } \\
\text { Lillebælt } \\
\text { (L2) } \\
\text { argillised } \\
\text { needles }\end{array}$ \\
\hline $\begin{array}{l}\mathrm{Na}_{2} \mathrm{O} \\
\mathrm{MgO} \\
\mathrm{Al}_{2} \mathrm{O}_{3} \\
\mathrm{SiO}_{2} \\
\mathrm{~K}_{2} \mathrm{O} \\
\mathrm{CaO} \\
\mathrm{TiO}_{2} \\
\mathrm{MnO} \\
\mathrm{Fe}_{2} \mathrm{O}_{3}{ }^{*}\end{array}$ & $\begin{array}{r}8.18 \\
2.54 \\
11.95 \\
46.55 \\
3.54 \\
0.37 \\
0.40 \\
0.00 \\
8.35\end{array}$ & $\begin{array}{r}0.34 \\
4.09 \\
11.91 \\
50.78 \\
2.12 \\
0.88 \\
2.71 \\
0.07 \\
10.31\end{array}$ & $\begin{array}{r}0.14 \\
1.26 \\
12.18 \\
61.84 \\
1.71 \\
1.81 \\
0.34 \\
0.00 \\
1.08\end{array}$ & $\begin{array}{r}0.07 \\
4.20 \\
11.22 \\
50.51 \\
2.28 \\
0.65 \\
2.94 \\
0.10 \\
10.22\end{array}$ & $\begin{array}{r}1.89 \\
0.05 \\
13.46 \\
41.69 \\
2.90 \\
4.22 \\
0.28 \\
0.01 \\
0.91\end{array}$ & $\begin{array}{r}1.99 \\
0.05 \\
13.45 \\
41.77 \\
2.90 \\
4.21 \\
0.28 \\
0.00 \\
0.90\end{array}$ & $\begin{array}{r}0.90 \\
0.00 \\
17.61 \\
62.39 \\
13.06 \\
1.72 \\
0.02 \\
0.10 \\
0.48\end{array}$ & $\begin{array}{r}8.57 \\
3.21 \\
9.66 \\
45.30 \\
2.15 \\
0.50 \\
0.35 \\
0.05 \\
11.25\end{array}$ \\
\hline Total & 81.88 & 83.21 & 80.36 & 82.18 & 65.41 & 65.56 & 96.28 & 81.03 \\
\hline
\end{tabular}




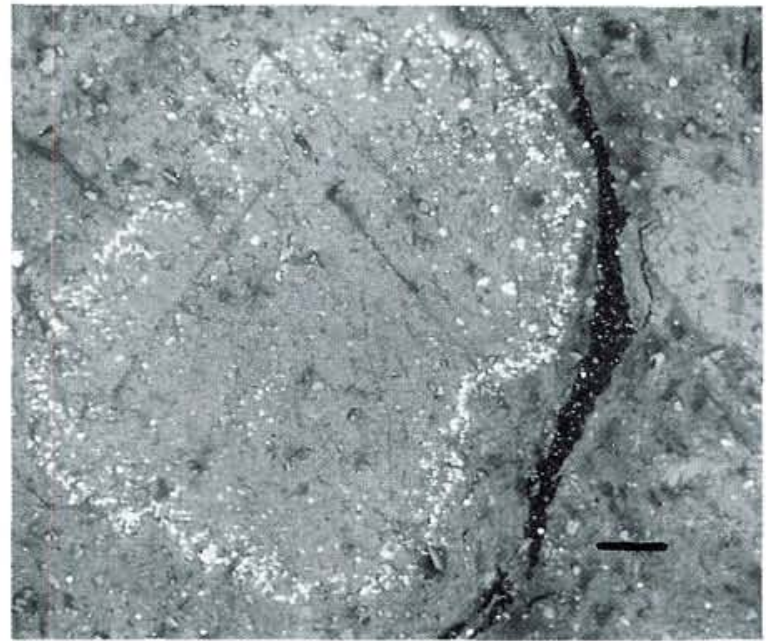

Fig. 14. Lillebælt Clay Formation (L2) from Ø1st. Smectite dominated claystone. The pyrite ring picks out the margin of a grain, probably glass, which has altered to clay (Table 7). Scale bar $=200 \mu \mathrm{m}$.

predicted to precipitate in preference to calcite as long as dissolved $\mathrm{Mn}^{2+}$ is available. However, saturation calculations (Holdren \& Bricker, 1977; Jakobsen \& Postma, 1989) for recent calcite and rhodochrosite in the Baltic Sea suggest that a high degree of supersaturation is required for significant precipitation. Dissolution of detrital calcite and dolomite may have supplied some bicarbonate for the Mn-rich carbonate cements. The presence of calcian rhodochrosite with rounded Mn-poor cores (Fig. 10) suggests that this may have occurred. However, it is possible that these rounded cores are globular aggregates

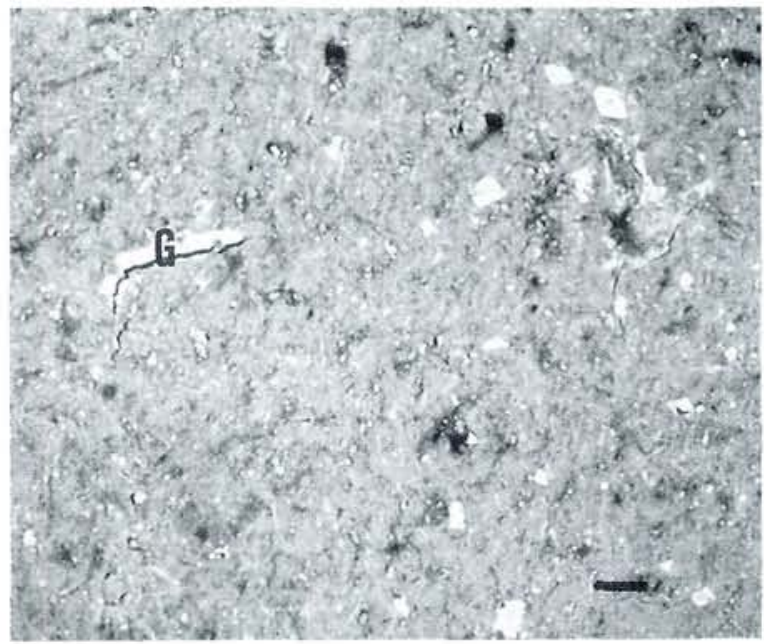

Fig. 15. Lillebælt Clay Formation (L3) from Ølst. Claystone with tabular shaped glass fragments $(\mathrm{G})$ and minor calcian rhodochrosite rhombs (white) which have nucleated onto clastic material (particles are too small to obtain analyses free from contamination). Scale bar $=100 \mu \mathrm{m}$.

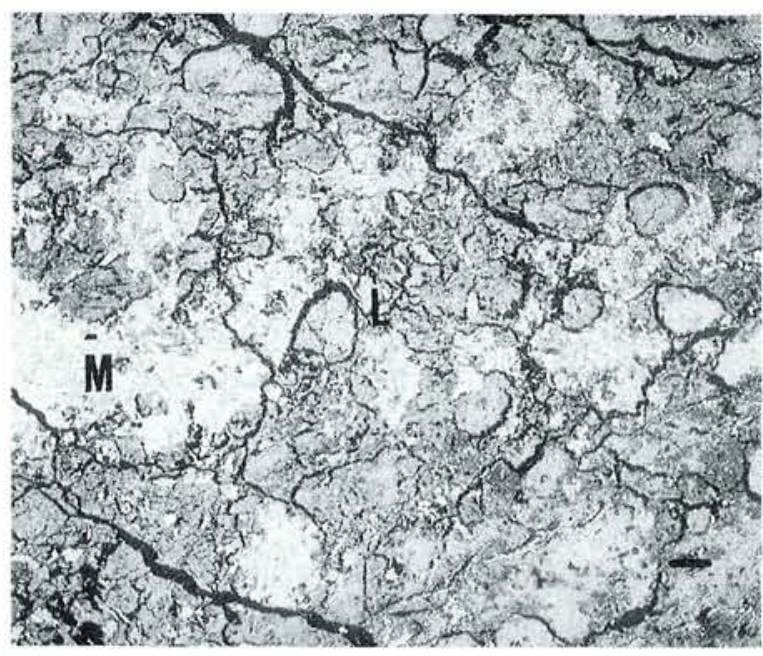

Fig. 16. Lillebælt Clay Formation (L4) from Ølst. Fecal pellets surrounded by clay of similar composition. The pellets have been partially cemented by pure micritic calcite $(\mathrm{M})$. Scale bar = $200 \mu \mathrm{m}$.

of carbonate as reported from recent Baltic Sea sediments by Jakobsen \& Postma (1989). The calcian rhodochrosite also occurs with cores of manganoan calcite which are equant, and therefore presumed to be an earlier diagenetic phase. This suggests that manganoan calcite started to precipitate as soon as $\mathrm{Mn}^{2+}$ became available. The manganoan siderite may have formed at the junction between the $\mathrm{Mn}^{4+}$ and $\mathrm{Fe}^{3+}$-reducing zones. In order for siderite to precipitate rather than pyrite, sulphate reduction must be inhibited. This will happen if all or most of the available organic matter is metabolised in the oxic and suboxic

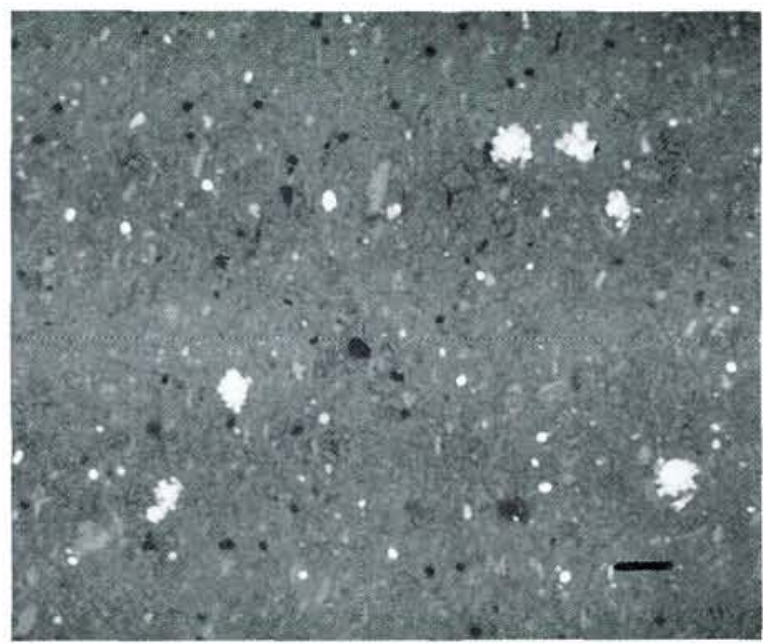

Fig. 17. Lillebælt Clay Formation (L4) from Ålbækhoved. Bioturbated claystone. L4 is the only bed sampled at Âlbakhoved which contains aggregates of pyrite crystals (white). Scale bar = $100 \mu \mathrm{m}$. 


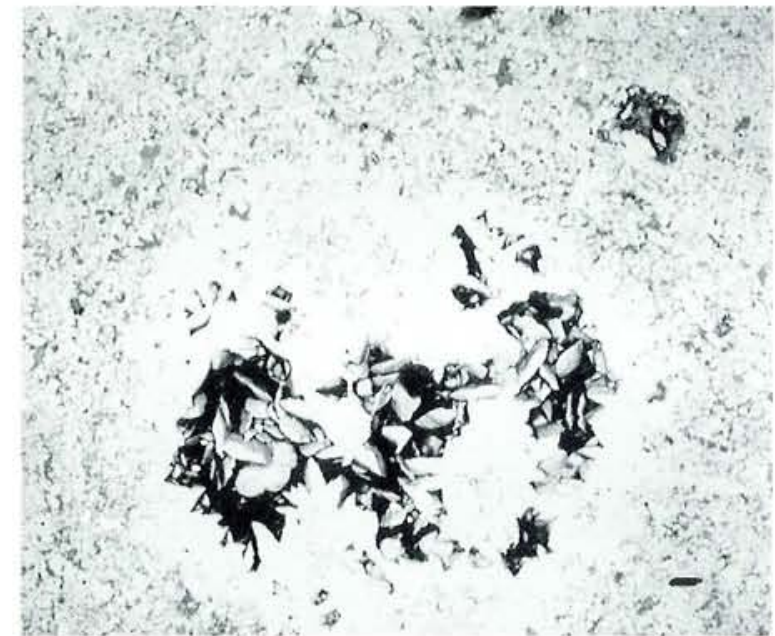

Fig. 18. Lillebælt Clay Formation (L4) from Ålbækhoved. Micritic mixed phase Fe-rich carbonate cement from a burrow wall (see Table 6 for analysis). Coarser carbonate of the same composition has partially cemented microfossil cavities. Scale bar = $100 \mu \mathrm{m}$.

(manganese reduction) zones, leaving insufficient organic matter for sulphate reduction. The presence of Fe/Mn carbonates and the scarcity of pyrite in the Søvind Marl, Lillebælt and Røsnæs Formations is therefore compatible with the anoxic-nonsulphidic environment of Berner (1981). Several beds in the Røsnæs and Lillebælt Formations are reddish brown in colour, this may also reflect a lack of iron reduction resulting from the limited supply of organic matter or a very low rate of sedimentation coupled with oxic bottom waters (the latter is compatible with the high degree of bioturbation). Nielsen, Baumann, Zhang, Heilmann-Clausen \& Larsen (1986) also recognised the Holmehus and Lillebælt Formations as predominantly anoxic non-sulphidic. They classified the Røsnæs Clay as oxic because of its high content of biogenic particles. The abundant $\mathrm{Mn}$-rich carbonates observed in this study (Figs 7,9 and 10) suggest that the carbonates in the Røsnæs Clay precipitated during burial through the anoxic non-sulphidic zone, rather than while still in fluid contact with oxic bottom waters.

For high concentrations of Mn-rich carbonates cements to precipitate requires high concentration of $\mathrm{Mn}$. Relatively high Mn concentrations are associated with the intervals containing ash layers (Nielsen, 1974, Nielsen et al. 1986). The Mn could therefore be derived from the ash. Analyses of glass particles from the Lillebælt and Røsnæs Formations indicate that they typically contain 400-1700 ppm manganese, whereas the average sea water concentration is $2 \mathrm{ppm}$ (Murray \& Brewer, 1977).

The substitution of $\mathrm{Ca}$ and $\mathrm{Mg}$ for $\mathrm{Fe}$ in the siderite cements in the Søvind Marl (Table 5), L4 and Ølst (Table 6 ) is characteristic of early marine siderite (Mozley (1989)). The substitution of $\mathrm{Mn}$ for Fe reflects the high concentration of $\mathrm{Mn}$ in these sediments.

\section{Non-carbonate authigenic minerals}

Non-carbonate authigenic minerals in these sediments are principally smectite with minor pyrite, whilst in several ash horizons heulandite-clinoptilolite has been identified by XRD, and in the single sample where it is present in more than trace amounts it has been observed in BSEM images (Fig. 5). All other authigenic minerals are present in trace amounts only.

Most of the clay minerals in these sediments are too fine-grained to assess from BSEM images whether they are authigenic or detrital. Smectite is only recognisable as authigenic where "ghost" outlines of grains which it has replaced can be identified (Fig. 14). These are particularly common in the ash horizons, where it is realistic to assume that all the smectite is authigenic and that it has replaced volcanic ash. The absence of relict feldspar or other volcanic minerals from these grain "ghosts" s except for the ash bed shown in Fig. 6 suggests that the precursor material was non-crystalline, i.e. glass. Glass particles have been detected, in the Haslund and Værum Members in particular, but no partially altered glass was observed. Whilst it is acknowledged that XRD is no better than semi-quantitative the presence of glass may be tentatively inferred from the particularly low XRD totals determined for the ash horizons. Visual estimates suggest that only a very small proportion of these low totals can be accounted for through the unquantified minerals identified from BSEM images.

In the clay sediments there may be a detrital smectite component, but it has not been possible to distinguish authigenic and detrital smectite in this study.

To determine the chemistry of the smectite, the composition of the pure smectite matrix in the Værum Member

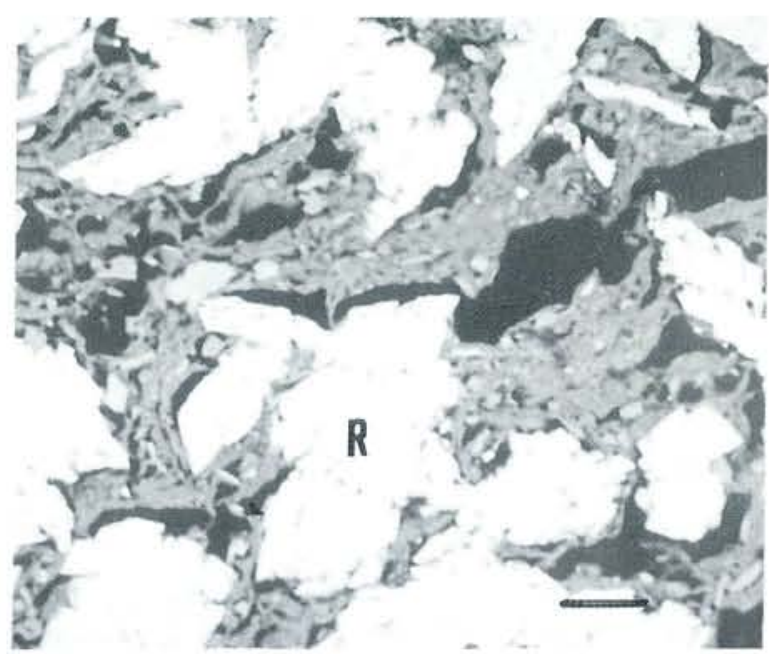

Fig. 19. Lillebælt Clay Formation (L4) from Ålbækhoved. Calcian rhodochrosite $(\mathrm{R})$ cemented burrow fill (see table 4 for analysis). This calcian rhodochrosite is unzoned and consists of coarser crystals than other calcian rhodochrosite cements observed at either locality. Scale bar $=100 \mu \mathrm{m}$. 
ash 2 from Ølst was determined by $x$-ray analysis in the SEM (this was the only smectite-rich ash from which it was possible to obtain uncontaminated data). The mean composition for these analyses is listed in Table 5. This composition indicates that the clay is Fe rich and al. poor compared with typical beidellites and montmorillonites. It is therefore described as an Fe-rich smectite. EDS analyses indicate that this clay contains approximately $8 \% \mathrm{Na}, 2-3.5 \% \mathrm{~K}$ and $<0.5 \% \mathrm{Ca}$. The most likely major interlayer cation is therefore $\mathrm{Na}$. Volcanic ash, unless deposited rapidly, will react with seawater prior to burial (Hatch, Wells \& Wells, 1961). The high Na content of the clay compared with the ash is therefore inferred to be derived from seawater.

Glaucony was identified in the Holmehus Formation, R1, R2 and L2 on the basis of bright green colour. However discrete glauconite pellets were not detected in the polished blocks examined in the SEM, consequently the identification is not unequivocal. Glaucony contains both ferric and ferrous iron, it is therefore a characteristic mineral of weakly reducing anoxic-non-sulphidic environments (Berner, 1981).

Kaolinite pseudomorphs after mica were observed in R5 and L3. This kaolinite may have formed in situ, as is commonly the case in mudrocks and sandstones (e.g. Huggett, 1984, Huggett \& Shaw, 1993).

Authigenic pyrite framboids are generally rare in these sediments. More than $1 \%$ pyrite was detected by XRD only in the Ølst Formation at Ålbækhoved (Table 3). The $\varnothing$ lst Formation is therefore classified as anoxic sulphidic. Early pyrite forms as a result of reaction between $\mathrm{Fe}^{2+}$ produced by reduction of $\mathrm{Fe}^{3+}$, and $\mathrm{S}^{2-}$ produced by sulphate reducing bacteria. In marine muds iron sulphides rather than carbonates usually replace unstable oxide phases (e.g. Curtis, Pearson \& Somogyi 1975, Berner, 1984). However in the majority of these sediments sulphate reduction appears to have been inhibited by a lack of organic matter. The sulphur in the Ølst Formation is probably derived from volcanic ash.

The diagenetic mineral suite described above is distinctly different from that described by Malm, Brunn Christensen, Furnes, Løvlie \& Rueslatten (1984) from the Balder Formation in the north Viking Graben. They recorded a predominance of microquartz, swelling chlorite, chlorite-smectite and smectite from the mudrocks and swelling chlorite, chlorite-smectite and chamositic clays, with subordinate pyrite, anatase (pore rimming as in the Ølst Værum Member ash examined in this study) and unspecified zeolites from the ashes. These differences probably reflects a combination of contrasting diagenetic environments and a higher proportion of detrital sediments derived from metamorphic rocks of Scandinavia.

\section{Conclusions}

Smectite and carbonate minerals are the principal authigenic phases in the Palaeogene clays of Ølst and Albakhoved.

Three manganese bearing carbonate cements have been identified in all Formations sampled at both localities except the Holmehus Formation. These cements are manganoan calcite, calcian rhodochrosite and manganoan siderite. The association of $\mathrm{Mn}$-rich carbonates with negligible pyrite indicates that sulphate reduction has been inhibited. This will happen if all or most of the available organic matter is metabolised in the oxic and sub-oxic zones, leaving insufficient organic matter for sulphate reduction. This scenario is compatible with precipitation in the anoxic-nonsulphidic environment of Berner (1981). Relatively high Mn concentrations are associated with the intervals containing ash layers (Nielsen, 1974, Nielsen et al. 1986). The Mn could therefore be derived from the ash.

Smectite is the most abundant clay in these sediments. It is only recognisable as authigenic where "ghost" outlines of grains which it has replaced can be identified. These are particularly common in the ash horizons, where it is realistic to assume that it has replaced volcanic ash. Where smectite can be unequivocally identified as authigenic it is rich in $\mathrm{Fe}$ and $\mathrm{Na}$. The high $\mathrm{Na}$ content of the clay compared with the ash is inferred to be derived from seawater. The absence of relict feldspar or other volcanic minerals from the majority of the grain "ghosts" suggests that the precursor material was non-crystalline, i.e. glass. Whilst it is acknowledged that XRD is no better than semi-quantitative the presence of glass may be tentatively inferred from the particularly low XRD totals determined for the ash horizons.

\section{Acknowledgements}

Ole Nielsen is kindly thanked for his assistance with sampling at $\varnothing \mathrm{lst}$ and Ålbækhoved.

\section{Dansk sammendrag}

Petrologien og diagenesen i de Paleocæne og Eocæne ler bjergarter (Holmehus Leret, Ølst Formationen, Røsnæs Formationen, Lillebælt Leret og Søvind Mergelen) er blevet undersøgt i prøver fra lokaliteterne Ølst og Albækhoved i Østjylland. Prøverne er undersøgt ved "backscattered" elektronmikroskopi (BSEM) og røntgendiffraktometri (XRD). Sedimenterne er ekstremt finkornede, brogede, smectitrige lerbjergarter, hvor vulkanske askelag optræder i flere stratigrafiske niveauer. Smectit og karbonatmineraler er de vigtigste nydannede (authigene) mineraler. Smectit formodes at være dannet ved omdannelse 
af vulkansk glas, da smectit indholdet er størst i de askeførende niveauer, men smectit kan også være tilført fra land. Mængdeforholdet mellem nydannet og aflejret (detritalt) smectit kan sjældent bestemmes. Nydannet smectit kan kun påvises sikkert, hvor spøgelsesagtige omrids af de replacerede korn kan genkendes. Disse er sarligt hyppige $\mathrm{i}$ aske niveauerne, hvorfor det formodes, at smectit har replaceret vulkansk aske. Hvor smectit med sikkerhed kan identificeres som nydannet, er Fe- og Naindholdet stort. Da Na-indholdet er større i leret end i asken formodes det, at Na stammer fra havvandet. Blandt de spøgelsesagtige korn mangler feldspater og andre vulkanske mineraler, hvilket tyder på, at udgangsmaterialet var non-krystallinsk, d.v.s. vulkansk glas. Selvom XRD metoden kun er semikvantitativ, kan de særligt lave totalværdier tolkes som udtryk for tilstedeværelsen af glas. Tre manganholdige karbonatmineraler, Mn-calcit, Carhodochrosit og Mn-siderit, optræder som cement i alle de unders $\emptyset$ gte formationer undtagen Holmehus Leret. Cementmineralerne formodes at være udfældet under anoxiske, non-sulfidiske betingelser (Berner 1981). De relativt høje Mn-koncentrationer findes i de askerige stratigrafiske niveauer (Nielsen 1974, Nielsen et al. 1986). Mangan kunne derfor stamme fra den vulkanske aske.

\section{References}

Berner, R. A. 1981: A new geochemical classification of sedimentary environments. J. Sed. Petrol. 51, 359-365.

Berner, R. A. 1984: Sedimentary pyrite formation: an update. Geochimicha et Cosmochimicha Acta 48, 605-615.

Brindley, G. W. \& Brown, G. 1980: Crystal structure of clay minerals and their X-ray identification. minerals and their X-ray identification. Min. Soc. Monograph 5, Mineralogical Society, London. 495 pp.

Calvert, S. E. \& Price, N. B. 1970: Composition of manganese nodules and manganese carbonates from Loch Fyne, Scotland. Contrib. Mineral. Petrol. 29, 215-233.

Coleman, M. L., Fleet, A. \& Donson, P. 1982: Preliminary studies of manganese-rich carbonate nodules from leg 68, site 503, Eastern Equatorial Pacific. In Initial reports of the Deep Sea Drilling Project, LXVIII US Govt. Printing Office, Washington. 481-489.

Curtis, C. D. 1987: Mineralogical Consequences of Organic matter degradation in sediments: inorganic/organic diagenesis. In Leggett, J. K. \& Zuffia, G. G. (edit.) Marine Clastic Sedimentology, 108-123, Graham \& Trotman, London.

Curtis, C. D., Pearson, M. J. \& Somogyi, V. A. 1975: Mineralogy, chemistry and origin of a concretionary siderite sheet (clay-ironstone band) in the Westphalian of Yorkshire. Min. Mag. 40, 385-93.

Curtis, C. D. \& Coleman, M. L. 1986: Controls on the precipitation of early diagenetic calcite, dolomite and siderite concretions in complex depositional sequences. In Gautier, D. L. (edit.) Roles of organic matter in sediment diagenesis. Society of Economic Palaeontologists \& Mineralogists Spec. Publ. 38. 23-33.

Froelich, P. N., Klinkhammer, G. P., Bender, M. L., Luedtke, N. A., Heath, G. R., Cullen, D., Dauphin, P., Hammond, D., Hartman, B. \& Maynard, V. 1979: Early oxidation of organic matter in pelagic sediments of the eastern equatorial Atlantic: sub-oxic diagenesis. Geochim. Cosmochim. Acta. 43: 10751090.
Hatch, F. K., Wells, A. K. \& Wells, M. K. 1961: Petrology of the igneous rocks. Murby \& $\mathrm{Co}$., London.

Heilmann-Clausen C., Nielsen O. B. \& Gersner F. 1984: Lithostratigraphy and depositional environments in the Upper Paleocene and Eocene of Denmark. Bull. Geol. Soc. Denmark 33, 287-323.

Holdren, G. R. \& Bricker, O. P. 1977: Distribution and control of dissolved iron and manganese in the interstitial waters of Chesaspeake Bay. Pp. 178-196 In Drucker, H. \& Wildung, R. F. (edit.) Biological implications of metals in the environment. ERDA Symp. Ser.

Huggett, J. M. 1984: An SEM study of phyllosilicates in a Westphalian Coal Measures sandstone using back-scattered electron imaging and wavelength dispersive spectral analysis. Sed. Geol. 40, 233-247.

Huggett, J. M. \& Shaw, H. F. 1993: Diagenesis of Jurassic Mudrocks of the North Sea. In Manning, D. A. C., Hall, P. L. \& Hughes, C. R. (edit.) Geochemistry of Clay-Pore Fluid interactions. 107-125. Chapman \& Hall, London.

Jakobsen, R. \& Postma, D. 1989: Formation and solid solution behaviour of $\mathrm{Ca}$-rhodochrosites in marine muds of the Baltic deeps. Geochim. Cosmochim. Acta. 53: 2639-2648.

Li, Y. H., Bishchoff, J. \& Mathieu, G. 1969: The migration of manganese in the Arctic Basin sediments. Earth Planet. Sci. Letters 7, 265-270.

Lynn, D. C. \& Bonatti, E. 1965: Mobility of manganese in diagenesis of deepsea sediments. Mar. Geol. 3, 457-474.

Malm, O. A., Christensen, O. B., Furnes, H., Løvlie, R. \& Rueslatten, H. 1984: The Tertiary Balder Formation: an organogenetic and tuffaceous deposit in the North Sea region. In Spencer, A. M. (Edit.) Petroleum Geology of the North European Margin. 149-170. Graham \& Trotman, London.

Mannheim, F. T. 1982: Geochemistry of manganese carbonates in the Baltic Sea. Stockholm Contrib. Geol. 37, 145-159.

Mozley, P. S. 1989: Relation between depositional environment and the elemental composition of early diagenetic siderite. Geology 17. 704-706.

Murray, J. W. \& Brewer, P. G. 1977: Mechanisms of removal of manganese, iron and other trace metals from seawater. In Glasby, G. P. (edit.) Marine manganese deposits. 291-325. Elsevier, Amsterdam.

Nielsen, O. B. 1974: Sedimentation and diagenesis of lower Eocene sediments at Ølst, Denmark. Sed. Geol. 12, 25-44.

Nielsen, O. B. 1980: A sedimentological mineralogical investigation of the Tertiary sediments from the borehole $\mathrm{M}-2 \mathrm{X}$ in Central Trough, North Sea. Danmarks Geologiske Undersøgelse, Årbog. 1979, 41-50.

Nielsen, O. B., Baumann, J., Zhang, D., Heilmann-Clausen, C. \& Larsen, G. 1986: Tertiary deposits in Store Bxlt, the Tertiary section of borehole D. G. I. 83101, Østerenden, Store Bæilt, Denmark. In Møller, J. T. (edit.) Twentyfive years of Geology in Aarhus. Geoskrifter 25, 235-253.

Nielsen, O. B. \& Heilmann-Clausen, C. 1988: Palaeogene volcanism: the sedimentary record in Denmark. In Morton, A. C. \& Parson, L. M. (edit). Early Tertiary Volcanism and the opening of the NE Atlantic. Geol. Soc. Spec. Publ. 39, 395405.

Schultz, L. G. 1964: Quantitative interpretation of mineralogical composition from X-ray and chemical data for the Pierre Shale, US Geol. Surv. Prof. Paper 391-C: 31.

Shaw H. F. 1972: The preparation of oriented clay mineral specimens for $\mathrm{x}$-ray diffraction analysis by a suction-ontoceramic-tile method. Clay Miner. 3, 349-350.

Thiede, J., Nielsen, O. B., \& Perch-Nielsen, K. 1980: Lithofacies, Mineralogy and Biostratigraphy of Eocene Sediments in Northern Denmark (Deep test Viborg 1). Jb. Geol. Palaeont. Abh. 160, 149-172.

Unmack, A. 1949: X-ray investigation of some Danish clays. II. Montmorillonite clays. Roy. Vet. Agric. Coll. Copenhagen Yearbook 1949. 192-204.

Zhang, D. 1986: Clay mineralogy of the Upper Paleocene and Eocene sediments in Denmark. Bull. Geol. Soc. Denmark 36, 249-258. 